Journal of Bangladesh Academy of Sciences, Vol. 36, No. 2, 221-226, 2012

\title{
GROWTH AND FLOWERING PERFORMANCE OF POTTED GERBERA, GERBERA JAMESONII L. UNDER DIFFERENT LIGHT INTENSITY
}

\author{
A.F.M. JAMAL UDDIN*, C. DAS, F.H. SHAMMY, M. FOYSAL AND M.S. ISLAM \\ Department of Horticulture, Sher-e-Bangla Agricultural University, Dhaka
}

\begin{abstract}
The influence of different light intensities ( $\mathrm{L}_{0}$ : full sunlight; $\mathrm{L}_{1}$ : reduced sunlight; $\mathrm{L}_{2}: 60 \%$ reduced sunlight) showed significant variations on growth and flower characteristics. Forty per cent reduced sunlight was more effective on growth and flower production than $60 \%$ reduced or in full sunlight. Tallest and thickest peduncles were produced $\left(28.5\right.$ and $1.7 \mathrm{~cm}$, respectively) with $\mathrm{L}_{1}$, similarly bigger flowers $\left(6.0 \mathrm{~cm}\right.$ diameter) were also found with $\mathrm{L}_{1}$ in comparison to $\mathrm{L}_{\mathrm{o}}$ and $\mathrm{L}_{2}$. The maximum number of flowers per plant (15.6) was found from $L_{1}$ and lowest (11.9) from $L_{2}$.
\end{abstract}

Key words: Gerbera jamesonii, Light intensity, Growth, Flower yield

\section{INTRODUCTION}

Gerbera, Gerbera jamesonii L. belonging to Asteraceae is an herbaceous perennial popular cutflower crop. In Bangladesh, gerbera introduced recently, is mainly grown in early summer, gaining popularity and has great potential for local as well as export market. Gerbera cannot tolerate extreme high temperature, cold, heavy rainfall and extreme sunlight. Sunburn is one of the major constraint of quality gerbera production. During the flowering season high light intensity reduces the length and width of the peduncle and the size of flowers. The flowers producers can grow gerbera in low light or shading condition. So, there is a need to screen gerbera under low light environment for evaluating their adaptability and yield potentiality.

As a few research work related to growth, yield and development of gerbera in reduced light have been carried out in Bangladesh, the present study was conducted to find out the influence of light intensity on potted gerbera production.

\section{MATERIALS AND METHODS}

The study was conducted in the Horticulture Farm, Sher-e-Bangla Agricultural University, Sher-e-Bangla Nagar, Dhaka, Bangladesh during December, 2009 to April, 2010 to find out the influence of different light intensity on growth and yield of potted gerbera. The experiment was laid out in complete randomized design with three replications. Same aged seedlings were collected from local nursery, Dhaka. Soil and

\footnotetext{
*Corresponding author:<jamal4@yahoo.com>.
} 
cow-dung (1:1) were mixed and pots were filled 7 days before transplanting. Recommended chemical fertilizers (NPK as 5, 10, and $5 \mathrm{~g}$, respectively in each pot) were mixed with the soil.

Three levels of light intensity i.e., $\mathrm{L}_{0}$ : Full sunlight (10000 lux or more); $\mathrm{L}_{1}$ : 40\% reduced sunlight (6000 - 6500 lux); and $\mathrm{L}_{2}: 60 \%$ reduced sunlight (2500 - 4000 lux) were maintained in this experiment. Fifteen days after transplanting (DAT), one or two layers of nylon nets were placed at a height of 1.5 meters with bamboo sticks to maintain desire light intensity. Single layer net reduced the light intensity up to $40 \%$ and double layer net up to $60 \%$ and for full sunlight there was no net cover.

Data were collected on number of leaves per plant, leaf length, leaf width, leaf area, diameter of flower bud, days to bud appearance to anthesis, peduncle length and diameter, diameter of flower and flower per plant from each pot within the period mentioned above. Number of leaves, length and width of leaves were measured at every 20 days interval from 20 DAT and continued up to 140 DAT. Diameter of flower bud and peduncle and length of peduncle were recorded using Digital Caliper-515 (DC-515) at every one day interval. Leaf area was measured by using CL-202 Leaf Area Meter at the mature stage.

Leaf area, appearance of flower bud, anthesis and flowers per plant were statistically analyzed using MSTATC program. Mean for all the treatments was calculated and the analysis of variance for each of the characters was performed by $F$ test. Difference between treatments was evaluated by DMRT at the 5\% level of significance (Gomez and Gomez 1984).

\section{RESULTS AND DISCUSSION}

Data on different growth parameters and yield performance were recorded and presented here.

Significant variation was recorded in number of leaves per plant at different days after transplanting with different light intensity. At 20, 40, 60, 80, 100, 120 and 140 DAT maximum number of leaves per plant were 12.0, 19.5, 23.4, 28.5, 31.5, 35.8 and 37.3 in $\mathrm{L}_{1}$ which was closely followed as $11.2,18.8,22.6,26.0,30.5,33.3$ and 34.7 by $\mathrm{L}_{0}$ and the minimum number of leaves per plant $\left(9.9,16.7,20.6,22.4,25.9,28.6\right.$ and 32.1) in $\mathrm{L}_{2}$ (Fig. 1). Kubota and Hamid (1992) reported that under low light condition, plant provide more energy to vegetative growth compared to the plant grown under full sunlight. Haque et al. (2009) found that the number of leaves per plant decreased due to the reduced light levels. Pathiratna and Perera (2005) also reported similar results.

Different light intensity on potted gerbera showed statistically significant variation on leaf length with days after transplanting. Longest leaf (8.8, 11.0, 15.4, 18.6, 24.7, 28.9 and $30.4 \mathrm{~cm})$ was recorded in $\mathrm{L}_{1}$ which was closely followed $(7.4,9.5,13.1,17.0,20.4,25.0$ and 
$27.3 \mathrm{~cm})$ by $\mathrm{L}_{0}$; whereas the shortest leaf $(6.0,7.8,10.2,13.3,18.0,19.0$ and $22.3 \mathrm{~cm}$, respectively) was recorded in $\mathrm{L}_{2}$ at 20, 40, 60, 80, 100, 120 and 140 DAT (Fig. 2).

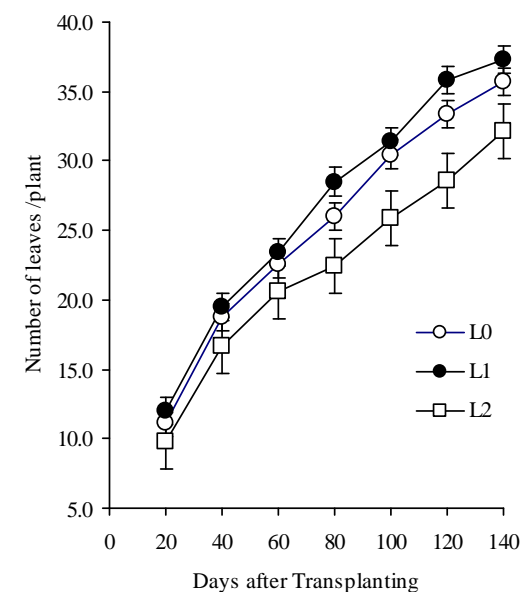

Fig. 1. Effect of light intensity on number of leaves per plant of gerbera; $\mathrm{L}_{0}$ : Full sunlight, $\mathrm{L}_{1}: 40 \%$ reduced sunlight and $\mathrm{L}_{2}-: 60 \%$ reduced sunlight.

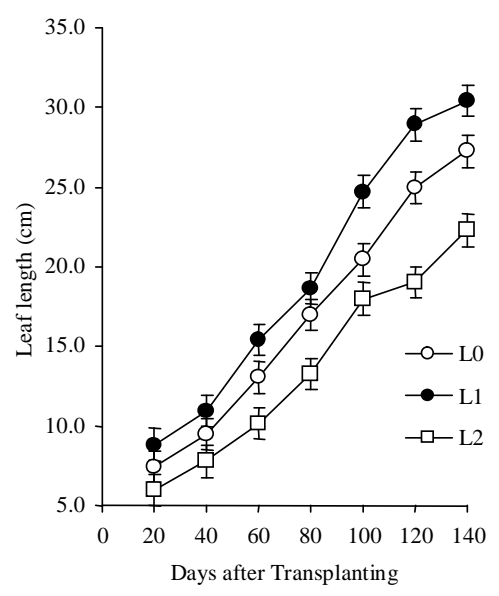

Fig. 2. Effect of light intensity on length of leaves of gerbera.

Leaf width showed significant variation with days after transplanting for different light intensity. Widest leaf $(4.4,7.6,8.8,9.2,11.8,15.2$ and $16.3 \mathrm{~cm})$ was found in $\mathrm{L}_{1}$ which was closely followed $(4.0,5.6,7.6,8.8,11.3,13.6$ and $15.8 \mathrm{~cm})$ by $\mathrm{L}_{0}$ and the shortest leaf $(3.0,3.8,5.7,8.2,9.9,11.1$ and $13.5 \mathrm{~cm})$ was recorded in $\mathrm{L}_{2}$ at 20, 40, 60, 80, 100, 120 and 140 DAT, respectively (Fig. 3). Wang et al. (2007), Pathiratna and Perera (2005) also reported similar results from their experiments.

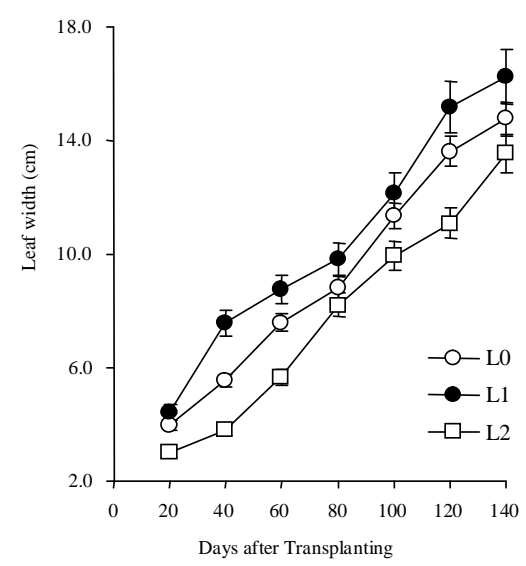

Fig. 3. Effect of light intensity on leaf width of gerbera.

Maximum leaf area $\left(38.4 \mathrm{~cm}^{2}\right)$ was found from $\mathrm{L}_{1}(40 \%$ reduced sunlight) which was closely followed $\left(36.5 \mathrm{~cm}^{2}\right)$ by $\mathrm{L}_{0}$ and the minimum $\left(31.0 \mathrm{~cm}^{2}\right)$ was recorded from $\mathrm{L}_{2}$ 
(Table 1). Under partial shade condition, stimulation of cellular expansion and cell division in leaf could be one of the possible factors that contribute to the individual leaf area increase (Schoch 1982)

Tallest peduncle $(1.6,9.4,18.0,22.7,24.2$ and $28.5 \mathrm{~cm})$ was observed in $\mathrm{L}_{1}$ which was closely followed $(1.5,7.4,16.0,19.4,23.5$ and $26.6 \mathrm{~cm})$ by $\mathrm{L}_{0}$ and the shortest peduncle $(1.4$, 7.1, 12.9, 17.0, 20.7 and $22.6 \mathrm{~cm}$ ) was recorded in $\mathrm{L}_{2}$ after flower bud appearance (Fig. 4). In $40 \%$ reduced sunlight, the concomitant increase in peduncle length was probably due to the apical dominance of flower bud under partial shade condition.

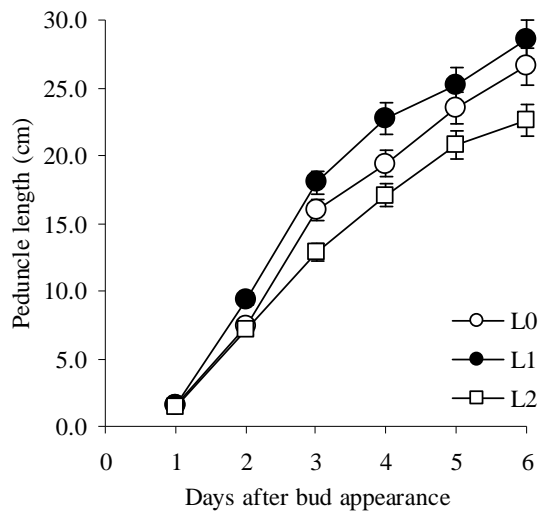

Fig. 4. Effect of light intensity on peduncle length of gerbera.

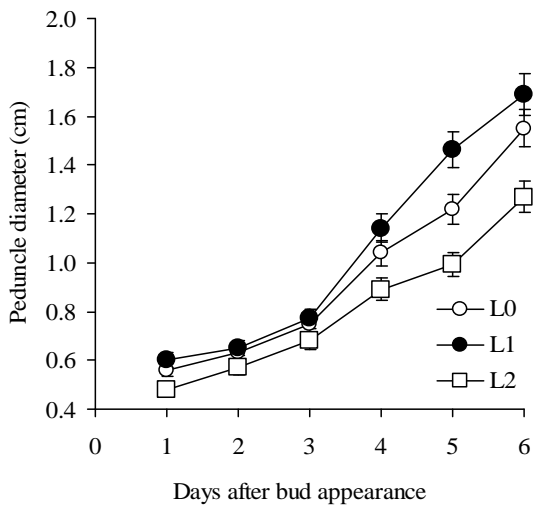

Fig. 5. Effect of light intensity on peduncle diameter of gerbera.

Maximum diameter of peduncle $(0.6,0.7,0.8,1.1,1.3$ and $1.7 \mathrm{~cm})$ was found in $\mathrm{L}_{1}$ which was closely followed $(0.6,0.6,0.8,1.0,1.2$ and $1.6 \mathrm{~cm})$ by $\mathrm{L}_{0}$ and the minimum $(0.48$, $0.57,0.68,0.89,0.99$ and $1.27 \mathrm{~cm}$ ) was recorded in $\mathrm{L}_{2}$ (Fig. 5).

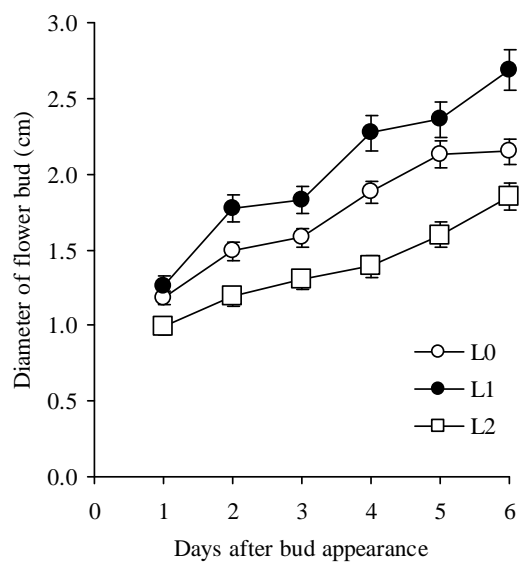

Fig. 6. Effect of light intensity on diameter of flower bud of gerbera.

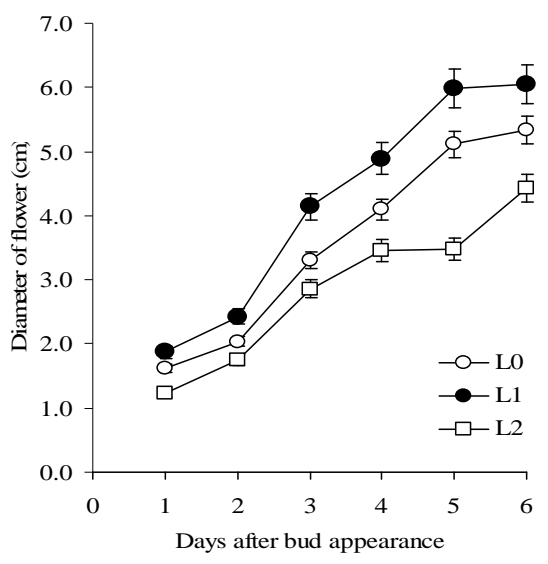

Fig. 7. Effect of light intensity on diameter of flower of gerbera. 
Maximum diameter of flower bud $(1.3,1.7,1.8,2.3,2.4$ and $2.7 \mathrm{~cm})$ was found in $\mathrm{L}_{1}$ which was closely followed $(1.2,1.5,1.6,1.9,2.1$ and $2.2 \mathrm{~cm})$ by $\mathrm{L}_{0}$ and the minimum $(1.0,1.2,1.3,1.4,1.6$ and $1.9 \mathrm{~cm})$ was recorded from $\mathrm{L}_{2}$ with days after bud appearance to flower bloom (Fig. 6).

Maximum diameter of flower $(1.9,2.2,4.1,4.4,6.0$ and $6.0 \mathrm{~cm})$ was found in $\mathrm{L}_{1}$ which was closely followed $(1.6,2.0,3.3,4.1,5.1$ and $5.8 \mathrm{~cm})$ by $\mathrm{L}_{0}$ and the minimum (1.2, 1.8, 2.9, 3.5, 3.5 and $3.5 \mathrm{~cm}$ ) was recorded in $\mathrm{L}_{2}$ (Fig. 7). Wang et al. (2007) and Pathiratna and Perera (2005) also reported similar results in cucumber and cinnamon respectively.

Table 1. Effect of light intensity on leaf area, days to initiation of flower bud and flowers per plant of potted gerbera*.

\begin{tabular}{|c|c|c|c|c|}
\hline \multirow[b]{2}{*}{ Treatment $^{* *}$} & \multirow{2}{*}{$\begin{array}{l}\text { Leaf area } \\
\qquad\left(\mathrm{cm}^{2}\right)\end{array}$} & \multicolumn{2}{|c|}{ Days to } & \multirow{2}{*}{$\begin{array}{c}\text { Flowers/ } \\
\text { plant }\end{array}$} \\
\hline & & $\begin{array}{l}\text { flowers bud } \\
\text { appearance }\end{array}$ & $\begin{array}{c}\text { flower } \\
\text { anthesis }\end{array}$ & \\
\hline $\mathrm{L}_{0}$ & $36.5 \mathrm{~b}$ & $109.4 \mathrm{c}$ & 6.6 & $14.1 \mathrm{~b}$ \\
\hline $\mathrm{L}_{1}$ & $38.4 \mathrm{a}$ & $115.5 \mathrm{~b}$ & 5.0 & $15.6 \mathrm{a}$ \\
\hline $\mathrm{L}_{2}$ & $31.0 \mathrm{c}$ & $125.5 \mathrm{a}$ & 5.3 & $12.0 \mathrm{c}$ \\
\hline $\operatorname{LSD}_{(0.05)}$ & 0.88 & 5.4 & NS & 0.266 \\
\hline $\mathrm{CV}(\%)$ & 3.35 & 4.3 & & 6.56 \\
\hline
\end{tabular}

*In a vertical column means having similar letter(s) do not differ significantly at 0.05 level of significance. ${ }^{* *} \mathrm{~L}_{0}=$ Full sunlight, $\mathrm{L}_{1}=40 \%$ reduced sunlight $\mathrm{L}_{2}=60 \%$ reduced sunlight.

Significant variation was observed for days to flower bud appearance under different light intensity. Maximum days to flower bud appearance (125.5 days) was required in $\mathrm{L}_{2}$ which was closely followed (115.5 days) by $\mathrm{L}_{1}$ and minimum days (109.4) was required in $\mathrm{L}_{0}$ (Table 1). There was no significance variation with days required to anthesis from bud appearance.

Number of flowers per plant varied significantly for different light intensity. The maximum number of flowers per plant (15.6) was found in $\mathrm{L}_{1}$ which was closely followed (14.1) by $\mathrm{L}_{0}$ and the minimum (11.9) was recorded in $\mathrm{L}_{2}$ (Table 1).

It can be concluded that photosynthetically active radiation is the major factor regulating photosynthesis, dry matter production and yield of crops (Rao and Mitra 1998). Excessive sun light causes crown death and sun burn of leaf in gerbera production. On the other hand due to much shading the growing period drops sharply, the peduncles become thinner and flowers become smaller. Excessive shading for long period affects negatively the assimilation rates and the production of flower. Limited shading affects positively the growth and yield of gerbera in Bangladesh conditions. 


\section{REFERENCES}

Gomez, K. H. and A. A. Gomez. 1984. Statistical Procedures for Agricultural Research. 2nd edn. Wiley- Inter Science Publication, John Wiley, New York. p. 680.

Haque, M. M., M. Hasanuzzaman and M. L. Rahman. 2009. Effect of Light Intensity on the Morpho-physiology and Yield of Bottle Gourd (Lagenaria vulgaris). Academic J. Plant Sci. 2(3): 158-161.

Kubota, F. and A. Hamid. 1992. Comparative analysis of dry matter production and photosynthesis between mungbean (Vigna radiata L.) and blackgram ( $V$. mungo L.) in different light intensities. J. Fac. Agr. Kyushu Univ. 37(1-2): 71-80.

Pathiratna, L.S.S. and M.K.P. Perera. 2005. Rubber (Hevea brasiliensis) cinnamon (Cinnamomum verum) intercropping system: Performance under standard inter row spacings of rubber. Natural Rubber Res. 18(2): 105-112.

Rao, L.J. and B.N. Mitra. 1998. Growth and yield of peanut as influenced by degree and duration of shading. J. Agron. Crop Sci. 160: 260-265.

Schoch, P.G. 1982. Effects of shading on structural characteristics of the leaf and yield fruit in Capsicum annum L. J. Amer. Soc. Hort. Sci. 97(4): 461-464.

Wang, S.H., S.X. Fan, Y. Kong and C. Qingjun. 2007. Effect of light quality on the growth and photosynthetic characteristics of cucumber Cucumis sativus L. under solar greenhouse. Acta Hort. 731: 243-249. 